\title{
Thrombocytopenia after sutureless aortic valve implantation: Comparison between Intuity and Perceval bioprostheses
}

\author{
Federica Jiritano, MD, Lucia Cristodoro, MD, Emanuele Malta, MD, and Pasquale Mastroroberto, MD, \\ Catanzaro, Italy
}

From the Cardiac Surgery Unit, Magna Graecia University of Catanzaro, Catanzaro, Italy.

Disclosures: Authors have nothing to disclose with regard to commercial support.

Received for publication April 13, 2016; revisions received July 9, 2016; accepted for publication July 16, 2016; available ahead of print Aug 26, 2016.

Address for reprints: Federica Jiritano, MD, Cardiac Surgery Unit, University of Magna Graecia, Catanzaro 88100, Italy (E-mail: fede.j@hotmail.it).

J Thorac Cardiovasc Surg 2016;152:1631-3

$0022-5223 / \$ 36.00$

Copyright (C) 2016 by The American Association for Thoracic Surgery

http://dx.doi.org/10.1016/j.jtcvs.2016.07.054

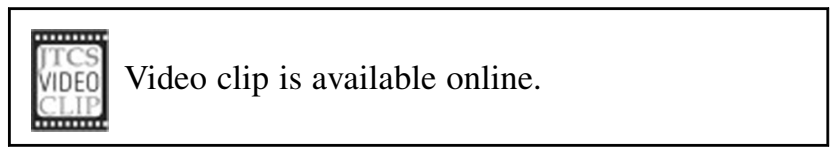

Aortic valve replacement continues to be the "gold standard" for the treatment of severe symptomatic aortic stenosis. The development of alternative techniques for the treatment of aortic stenosis (transcatheter aortic valve implantation) has encouraged research of new prostheses and less-invasive and quicker techniques for sutureless valves. The Sorin Perceval S sutureless valve (Sorin Group, Saluggia, Italy) and the Edwards Intuity rapid deployment valve system (Edwards Lifesciences LLC, Irvine, Calif) belong to the "sutureless family." The aim of this study was to analyze whether the use of a specific sutureless bioprosthesis is linked to postoperative thrombocytopenia.

\section{PATIENTS AND METHODS}

Isolated aortic valve replacement with the Edwards Intuity and Sorin Perceval S bioprostheses was performed in 43 patients divided into 2 groups: 27 in the Edwards Intuity group and 16 in the Sorin Perceval S group (Video 1). Patients' data are shown in Table 1. The study was approved by the institution's Ethical Committee/Institutional Review Board, and informed consent was obtained from each patient.

All patients received low-molecular-weight heparin postoperatively. Warfarin was commenced on postoperative day 1 and administered for 3 months, and then all patients were administered antiplatelet therapy. Variations in platelet count (PLT), mean platelet volume (MPV), and platelet distribution width (PDW) were observed preoperatively; at postoperative days 1, 3, and 5; at discharge; and at 1-year follow-up. Postoperative thrombocytopenia was defined as a PLT less than $50 \times 10^{9} / \mathrm{L}$ within the first 5 postoperative days. The study end point was the lowest PLT within the first 5 postoperative days.

Statistical analysis was performed with the SPSS program for Macintosh, version 21.0 (IBM SPSS Statistics for Macintosh, Armonk, NY) checking data for normality with the Shapiro-Wilk test. Unpaired $t$ test and Mann-Whitney $U$ test were used for normally distributed variables and not normally distributed variables, respectively. A multivariate analysis was performed. A $P$ value $\leq .05$ was considered statistically significant.

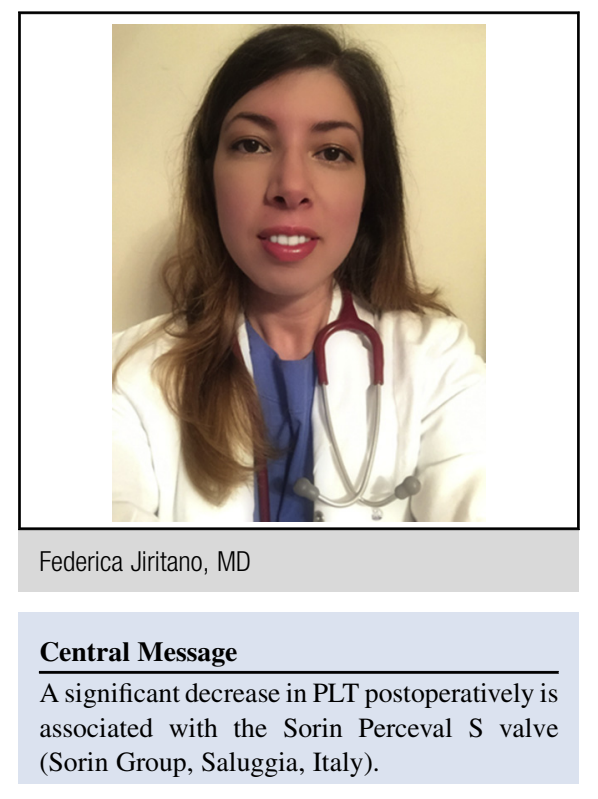

See Editorial Commentary page 1633.

\section{RESULTS}

No reexplorations for bleeding were performed. No operative mortality and major cardiovascular events were observed. From day 3 onward, a different PLT behavior was observed between groups (Table 2). In the Edwards Intuity group, a steady increase continued until discharge, but without reaching preoperative values. In the Sorin Perceval S sutureless valve group, a marked decrease of the PLT was observed on day 3 , followed by a slight increase on day 5 ; mild improvement was observed at discharge, although never reaching the preoperative value. The mean PLT was significantly higher in the Edwards Intuity group than in the Sorin Perceval S sutureless valve group from day 3 to discharge $(P<.01)$. MPV significantly increased in the Sorin Perceval S group from day 1 to 5. PDW was significantly higher in the Sorin Perceval $S$ group compared with the Edwards Intuity group on days 3 and 5 (Table 2). On multivariate analysis, the following independent risk factors for postoperative thrombocytopenia were revealed: age, body surface area, preoperative PLT, cardiopulmonary bypass time, and units of red blood cells. When the type of bioprosthesis was included in the multivariate analysis with the other risk factors, there was a statistically significant difference in PLT based on the type of prosthesis 


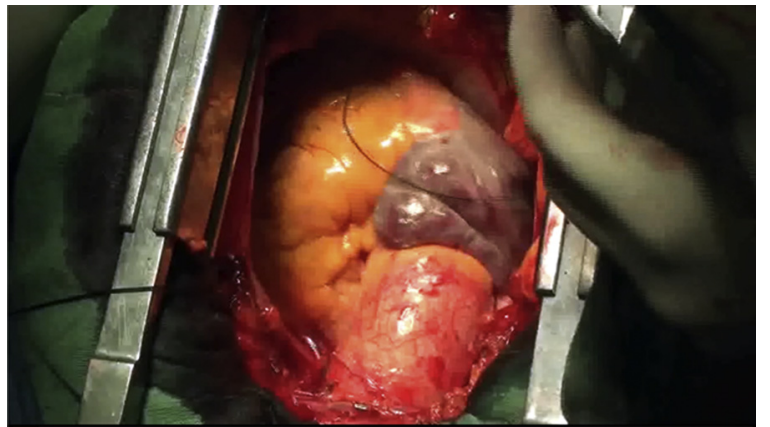

VIDEO 1. Hypothermic cardiopulmonary bypass was performed, and cold crystalloid cardioplegia was infused antegrade into the aortic root and retrograde into the coronary sinus. A transverse aortotomy was performed, and cold crystalloid cardioplegia was selectively administered into both coronary ostia. Excision of the aortic valve and annulus decalcification are shown. Sizing, lowering, and delivering of the prosthesis size M (Sorin Perceval S; Sorin Group, Saluggia, Italy) are shown. Postdilation modeling, closure of the aortotomy, and weaning from cardiopulmonary bypass are shown. Video available at: http://www.jtcvsonline.org/article/S0022-5223(16)30874-1/addons.

implanted: $F(4,38)=10.89, P<.0005$; Wilk's $\Lambda=0.466$, partial $\eta^{2}=0.53$. The use of the Sorin Perceval S bioprosthesis was an independent predictor of postoperative thrombocytopenia. At 1-year follow-up, the PLT in the

TABLE 1. Preoperative, operative, and postoperative data (April 2013 to May 2015)

\begin{tabular}{|c|c|c|c|}
\hline \multirow[b]{2}{*}{ Parameter } & \multicolumn{2}{|c|}{ Prosthesis } & \multirow[b]{2}{*}{$\begin{array}{c}P \\
\text { value }\end{array}$} \\
\hline & $\begin{array}{c}\text { Edwards Intuity } \\
\text { Elite prosthesis } \\
\text { (Edwards } \\
\text { Lifesciences LLC, } \\
\text { Irvine, Calif) }(\mathbf{n}=\mathbf{2 7})\end{array}$ & $\begin{array}{c}\text { Sorin Perceval S } \\
\text { prosthesis (Sorin } \\
\text { Group, Saluggia, } \\
\text { Italy) }(\mathbf{n}=\mathbf{1 6})\end{array}$ & \\
\hline Age (y) & $73.37 \pm 6.79$ & $75.94 \pm 7.07$ & .621 \\
\hline Female gender & 9 & 6 & .606 \\
\hline $\operatorname{BSA}\left(\mathrm{m}^{2}\right)$ & $1.88 \pm 0.24$ & $1.77 \pm 0.19$ & .482 \\
\hline COPD & 4 & 2 & .678 \\
\hline Diabetes & 8 & 6 & .337 \\
\hline Smoking & 8 & 5 & .830 \\
\hline Hypertension & 12 & 9 & .931 \\
\hline Dyslipidemia & 6 & 4 & .690 \\
\hline LVEF (\%) & $51.04 \pm 7.82$ & $56.13 \pm 4.33$ & .096 \\
\hline MG (mm Hg) & $47.80 \pm 20.96$ & $54.67 \pm 20.02$ & .744 \\
\hline PG $(\mathrm{mm} \mathrm{Hg})$ & $70.33 \pm 22.48$ & $88.07 \pm 26.93$ & .340 \\
\hline $\begin{array}{l}\text { Logistic euroSCORE } \\
\text { II }(\%)\end{array}$ & $11.63 \pm 4.15$ & $9.26 \pm 4.49$ & .921 \\
\hline $\begin{array}{l}\text { Aortic crossclamp } \\
\text { time (min) }\end{array}$ & $40.77 \pm 2.42$ & $40.62 \pm 3.18$ & .156 \\
\hline CPB time (min) & $57.77 \pm 4.25$ & $61.75 \pm 5.62$ & .109 \\
\hline RBCs (units) & 7 & 10 & .012 \\
\hline Platelets (units) & 0 & 4 & $<.01$ \\
\hline ICU stay (h) & $32.89 \pm 6.40$ & $33.19 \pm 4.92$ & .117 \\
\hline In-hospital stay (d) & $7.26 \pm 1.87$ & $6.81 \pm 1.05$ & .367 \\
\hline
\end{tabular}

Preoperative data. $B S A$, Body surface area; $C O P D$, chronic obstructive pulmonary disease; $L V E F$, left ventricular ejection fraction; $M G$, mean transvalvular gradient; $P G$, peak transvalvular gradient; euroSCORE, European System for Cardiac Operative Risk Evaluation; $C P B$, cardiopulmonary bypass; $R B C$, red blood cell; $I C U$, intensive care unit.
TABLE 2. Platelet count, mean platelet volume, and platelet distribution width variation

\begin{tabular}{|c|c|c|c|}
\hline \multirow[b]{2}{*}{ Time } & \multicolumn{2}{|c|}{ Prosthesis } & \multirow[b]{2}{*}{$\begin{array}{c}P \\
\text { value }\end{array}$} \\
\hline & $\begin{array}{c}\text { Edwards } \\
\text { Intuity Elite } \\
\text { prosthesis } \\
(\mathbf{n}=\mathbf{2 7})\end{array}$ & $\begin{array}{c}\text { Sorin Perceval } \\
\text { S prosthesis } \\
(\mathbf{n}=16)\end{array}$ & \\
\hline PLT - preoperative $\left(\times 10^{9} / \mathrm{L}\right)$ & $243.59 \pm 74.07$ & $268.69 \pm 84.68$ & .470 \\
\hline PLT - d $1\left(\times 10^{9} / \mathrm{L}\right)$ & $143.93 \pm 54.68$ & $124.75 \pm 41.99$ & .517 \\
\hline PLT - d $3\left(\times 10^{9} / \mathrm{L}\right)$ & $140.67 \pm 49.63$ & $71.88 \pm 21.20$ & .004 \\
\hline PLT - d $5\left(\times 10^{9} / \mathrm{L}\right)$ & $177.77 \pm 76.68$ & $73.25 \pm 19.71$ & $<.001$ \\
\hline PLT - discharge $\left(\times 10^{9} / \mathrm{L}\right)$ & $213.11 \pm 74.04$ & $102.18 \pm 29.34$ & .001 \\
\hline PLT - 1-y follow-up & $266.92 \pm 46.83$ & $265.56 \pm 53.36$ & .460 \\
\hline MPV - preoperative $\left(\mu \mathrm{m}^{3}\right)$ & $7.79 \pm 0.68$ & $7.81 \pm 0.67$ & .996 \\
\hline MPV $-\mathrm{d} 1\left(\mu \mathrm{m}^{3}\right)$ & $8.31 \pm 0.43$ & $9.13 \pm 0.64$ & .040 \\
\hline MPV - d $3\left(\mu \mathrm{m}^{3}\right)$ & $8.73 \pm 0.49$ & $10.97 \pm 1.51$ & .001 \\
\hline MPV - d $5\left(\mu \mathrm{m}^{3}\right)$ & $8.65 \pm 0.78$ & $10.11 \pm 1.44$ & .015 \\
\hline MPV - discharge $\left(\mu \mathrm{m}^{3}\right)$ & $8.28 \pm 0.62$ & $8.97 \pm 0.82$ & .313 \\
\hline MPV - 1-y follow-up $\left(\mu \mathrm{m}^{3}\right)$ & $8.14 \pm 0.78$ & $8.01 \pm 0.62$ & .102 \\
\hline PDW - preoperative $(\%)$ & $14.26 \pm 1.24$ & $14.91 \pm 1.52$ & .301 \\
\hline PDW - d $1(\%)$ & $14.71 \pm 0.94$ & $15.27 \pm 1.33$ & .134 \\
\hline PDW - d $3(\%)$ & $14.34 \pm 1.12$ & $16.54 \pm 1.72$ & .018 \\
\hline PDW - d $5(\%)$ & $14.47 \pm 0.91$ & $16.21 \pm 1.60$ & .026 \\
\hline PDW - discharge $(\%)$ & $13.99 \pm 0.93$ & $15.85 \pm 1.57$ & .288 \\
\hline PDW - 1-y follow-up (\%) & $14.58 \pm 1.24$ & $14.40 \pm 1.02$ & .298 \\
\hline
\end{tabular}

Values in bold are statistically significant $(P \leq .05)$. PLT, Platelet count; $M P V$, mean platelet volume; $P D W$, platelet distribution width.

Sorin Perceval S group was not significantly different than the preoperative count, as well as in the Edwards Intuity group $(P=.063)$.

\section{DISCUSSION}

There are few studies on thrombocytopenia and sutureless valves. ${ }^{1,2}$ Albacker ${ }^{1}$ reported a comparison among sutureless prostheses and traditional sutured valves, and he concluded that thrombocytopenia is a transient phenomenon linked to sutureless valves with a significantly higher transfusion of red blood cells. Flameng and colleagues ${ }^{2}$ confirmed a decrease in PLT after Sorin Perceval S sutureless valve implantation up to 1 -year follow-up. ${ }^{2}$ Thrombocytopenia after Sorin Perceval S implantation could be a transitory direct toxic effect of these valves on platelets caused by the storage solution ${ }^{3}$ or the microhemodynamic effects of the prosthetic structure. ${ }^{4}$ Miceli and colleagues ${ }^{5}$ analyzed MPV and PDW, indices of platelet activation, reporting that the Sorin Freedom Solo bioprosthesis might induce thrombocytopenia. ${ }^{5}$ Likewise, in our study, MPV and PDW were higher in the Sorin Perceval $S$ group. The stainless-steel frame of the Edwards Intuity valve is hidden by a sealing cloth, whereas the alloy stent of the Sorin Perceval S valve is "naked." According to this observation, we might conclude that the type of stent may play a pivot role in platelet activation, resulting in thrombocytopenia. 


\section{Study Limitations}

The limitations of this study were linked to the limited number of cases and the retrospective analysis.

\section{CONCLUSIONS}

The results showed that the reduction in PLT depends on the type of sutureless bioprosthesis used. A significant but transient reduction in PLT is associated with the Sorin Perceval $\mathrm{S}$ valve without adverse outcomes, although larger prospective, randomized studies are mandatory.

\section{References}

1. Albacker TB. Thrombocytopenia associated with Perceval sutureless aortic valve replacement in elderly patients: a word of caution. Heart Surg Forum. 2015;18: E093-7.

2. Flameng W, Herregods MC, Hermans H, Van der Mieren G, Vercalsteren M, Poortmans G, et al. Effect of sutureless implantation of the Perceval S aortic valve bioprosthesis on intraoperative and early postoperative outcomes. J Thorac Cardiovasc Surg. 2011;142:1453-7.

3. Boldyrev AA. Molecular mechanisms of homocysteine toxicity. Biochemistry. 2009;74:589-98.

4. Hilker L, Wodny M, Ginesta M, Wollert HG, Eckel L. Differences in the recovery of platelet counts after biological aortic valve replacement. Interact Cardiovasc Thorac Surg. 2009;8:70-3.

5. Miceli A, Gilmanov D, Murzi M, Parri MS, Cerillo AG, Bevilacqua S, et al. Evaluation of platelet count after isolated biological aortic valve replacement with Freedom Solo bioprosthesis. Eur J Cardiothorac Surg. 2012;41:69-73.

\section{EDITORIAL COMMENTARY}

\section{Tissue valve, nitinol stent, or storage solution? The mystery still goes on}

\author{
Antonio Miceli, MD, PhD \\ From the Istituto Clinico Sant'Ambrogio, Gruppo Ospedaliero SanDonato, Milano, Italy; and the Department of \\ Clinical Science at South Bristol, University of Bristol, Bristol Royal Infirmary, Bristol, United Kingdom. \\ Disclosures: Author has nothing to disclose with regard to commercial support. \\ Received for publication July 28, 2016; accepted for publication July 30, 2016; available ahead of print Sept 1, \\ 2016. \\ Address for reprints: Antonio Miceli, MD, PhD, Istituto Clinico Sant'Ambrogio, Gruppo Ospedaliero SanDonato, \\ Via Faravelli 16, Milano, Italy (E-mail: antoniomiceli79@alice.it). \\ J Thorac Cardiovasc Surg 2016;152:1633-4 \\ $0022-5223 / \$ 36.00$ \\ Copyright (c) 2016 by The American Association for Thoracic Surgery \\ http://dx.doi.org/10.1016/j.jtcvs.2016.07.066
}

Thrombocytopenia is a frequent and transient event after cardiac surgery. It usually occurs between the second and third postoperative days and results in a reduction of platelet counts by $30 \%$ to $60 \%$ from baseline values. ${ }^{1}$ In this setting, cardiopulmonary bypass plays an important role in inducing qualitative and quantitative platelet defects, resulting in platelet activation (structural and biochemical changes), formation of platelet conjugates, altered platelet force generation, and thrombocytopenia. ${ }^{1}$ Furthermore, factors such as hemodilution, hypothermia, and the use of exogenous drugs, as well as the perioperative blood loss, may amplify these platelet changes. Finally, some studies have reported that some biologic valves might increase the risk of thrombocytopenia. ${ }^{2-4}$

In this issue of the Journal, Jiritano and colleagues ${ }^{5}$ have investigated whether the use of a specific sutureless bioprosthesis is linked to postoperative thrombocytopenia.

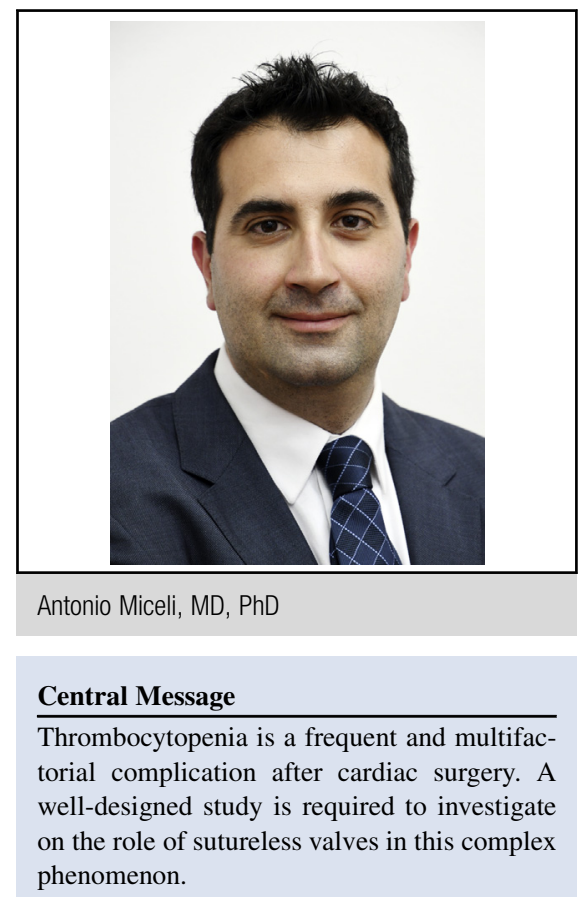

See Article page 1631.

Of 43 patients undergoing aortic valve replacement, 27 received the Intuity Edwards rapid-deployment valve 